ガーゴブロック，捲線式把手，空杵金物，ハッチクリート，ハシドレールスタンション金物等。

8. 汽罐用品

汽鑵用邪魔板，蒸發管用及び過熱管用邪㱱板，接合金具，取附金具，ブラケット，クランンフ等。

9. 自動車用品

フロントホキール, レーアホキール, フロントハブキャッブ, レーアホキールパッキングピース, ファン センター, レーアエクゾースパイプフランデ, クランクシアフト用プラッグ，レーアペヤリング，レーア スプリングハンガー，石油タンク支持チーブブラケット，サイレンサーフランヂ, レーアホキールクラン プ, クオードラントシヤフトブラケット,ブレーキチーブ用ブラケット,チェーンヂスピードブラケット, コンペンセーテングブレーキチーブブラヶット，レバー, チェーンヂスピードロック，ユニバーサルジョ イントソケット，ブレーキブラケットユニバーサルジョイントリング，アクスルケース等。

10. 機械及セメント工業用品

フルクラムサポーター,フルクラムキャップ. ピストンロッキングプレート，スターチングバルブレーバ 一, エキゾーストバルブレバー, フューエルバルブレバー等, バケット等。

11. 鑛山用品 ハンキングシープアーム，ガイドレール用クランプ，堅杭ケージ用ガイドショー等。

12. 紡績用品

ワーパースビームフランジ，オサ金物，ブラケット，フック等。

13. リンクチエーン

これは製糖，製粉工場，飲料，食料品工場，染色織物工場等，コンベーヤを使用してるる所には多數使用 され，本工場にては小は 25 番より大は 124 番まで製作在庫して居ります。

14. 農具及工具

黎金物，パイプバイス部分品，バラストフオーク等。

15. 瓦斯及水道工事用品

鐵管接手，サービスュック，異形管等。

其 他

数録

\title{
最近に於けるこ,ミの統計に就て
}

熊 澤 治 郎 吉

\section{I. 研碩材料及研硯碈}

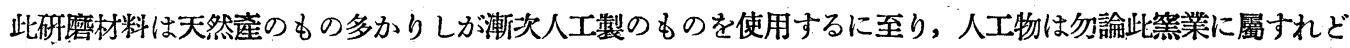
此工業に關しては比較的調查報告したものも眇ないと信ずるが故に弦に統計表より見たる本問題の輸入及生産 
狀態 (然か子も天然產品共) 並に其輸入及生產地方別を示して參考に供せんとす。

（1）我國に於ける矿磨仏料の天然產並に人工物の探集並に生產高及各府縣別表次の如し。

年次

4

5

6

7

\begin{tabular}{|c|c|}
\hline \multicolumn{2}{|c|}{ カーボランダム } \\
\hline 數量 (䣶) & 價格 (圓) \\
\hline 450 & 15,993 \\
\hline 6,750 & 33,450 \\
\hline 15,750 & 6,650 \\
\hline 94,500 & 45,328 \\
\hline
\end{tabular}

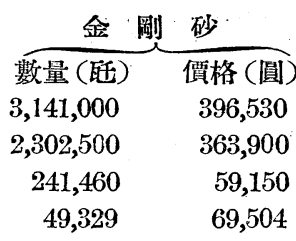

\begin{tabular}{|c|c|}
\hline 其 & 他 \\
\hline 数量 (䣶) & 價格 (圓) \\
\hline 527,673 & 167,749 \\
\hline 530,596 & 151,388 \\
\hline 534,565 & 124,119 \\
\hline $1,371,499$ & 390,395 \\
\hline
\end{tabular}

總價格

(圓)

580,572

548,738

189,919

505,227

昭和 7 年に於ける生產の地方別は次表の如し。

\begin{tabular}{|c|c|c|c|c|c|c|c|}
\hline \multirow[b]{2}{*}{ 府縣別 } & \multicolumn{2}{|c|}{ カーボランダム } & \multicolumn{2}{|c|}{ 金 㴊 砂 } & \multicolumn{2}{|c|}{ 其，他 } & \multirow{2}{*}{$\begin{array}{c}\text { 總 傾 格 } \\
\text { (圓) }\end{array}$} \\
\hline & 數量 (䣶) & 價格 (圓) & 數量 (䣷) & 價格 (圆) & 数量 (䣶) & 僨格 (圓) & \\
\hline 東 & - & 3,000 & - & - & 867,210 & 149,350 & $15: 350$ \\
\hline 野 & 94,500 & 42,328 & - & - & 6,750 & 2,250 & 44,578 \\
\hline 馬 & - & - & 4,259 & 25,254 & - & - & $25 ; 2$ \\
\hline 良 & - & - & 45,070 & 44,250 & - & - & 44,2 \\
\hline 神奈川 & - & - & - & - & 287,100 & 105,316 & 105,3 \\
\hline 大 阪 & - & - & - & - & 210,439 & 133,479 & 133,4 \\
\hline
\end{tabular}

（2）最近我國に於ける研碚用品の生座並に其地方別次表の如し。

\begin{tabular}{|c|c|c|c|c|c|c|}
\hline \multirow{2}{*}{ 年次 } & \multicolumn{2}{|c|}{ 人造䂸石 } & \multicolumn{2}{|c|}{ 研 磨紙 布 } & \multirow{2}{*}{$\begin{array}{l}\text { 其 } \\
\text { (想) }\end{array}$} & \multirow{2}{*}{ 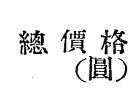 } \\
\hline & 數量（酕） & 價格 (圓) & 教量 (能) & 價格 (圓) & & \\
\hline 4 & 457,319 & 849,903 & - & 141,816 & 114,212 & $1,105,931$ \\
\hline 5 & 186,576 & 619,027 & - & 144,457 & 161,972 & 925,456 \\
\hline 6 & 363,854 & 704,001 & 92,600 & 102,963 & 13,128 & 830,092 \\
\hline 7 & 675,577 & $1,281,875$ & - & 69,215 & 32,195 & $1,383,26$ \\
\hline
\end{tabular}

昭和 7 年に於ける生產の地方別は次表の如し。

\begin{tabular}{|c|c|c|c|c|c|c|}
\hline \multirow{2}{*}{ 府縣別 } & \multicolumn{2}{|c|}{ 人 造 砥 石 } & \multicolumn{2}{|c|}{ 研磨紙 布 } & \multirow{2}{*}{ 其 } & \multirow{2}{*}{ 總 儥 格 } \\
\hline & 數量（䣶) & 價格 (傊) & 數量 (䣶) & 價格 (圓) & & \\
\hline 京 & -- & 43,000 & - & - & - & 43,000 \\
\hline 都 & 237,591 & 569,217 & - & - & - & 509,217 \\
\hline 阪 & 12,159 & 73,178 & - & 21,191 & 29,165 & 123,534 \\
\hline 庫 & 144,000 & 33,120 & - & 7,224 & 210 & 40,554 \\
\hline 島 & 281,827 & 623,360 & - & - & - & 623,360 \\
\hline 良 & - & - & - & 40,800 & - & 40,800 \\
\hline 媛 & - & - & - & - & 2,820 & 2,8 \\
\hline
\end{tabular}

（3）更に上記の材料及製品の輸大狀態を見るに次表の如きものあり。

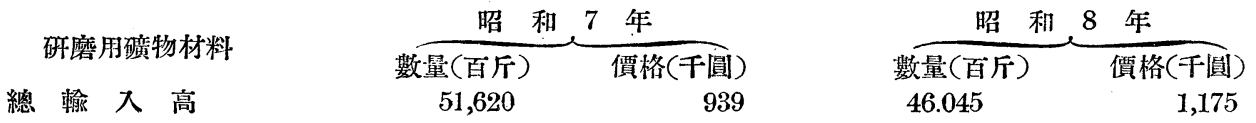

文最近三ケ年間に於ける輸入國別表の數量並に價格を表示すればとの通りなりとす。

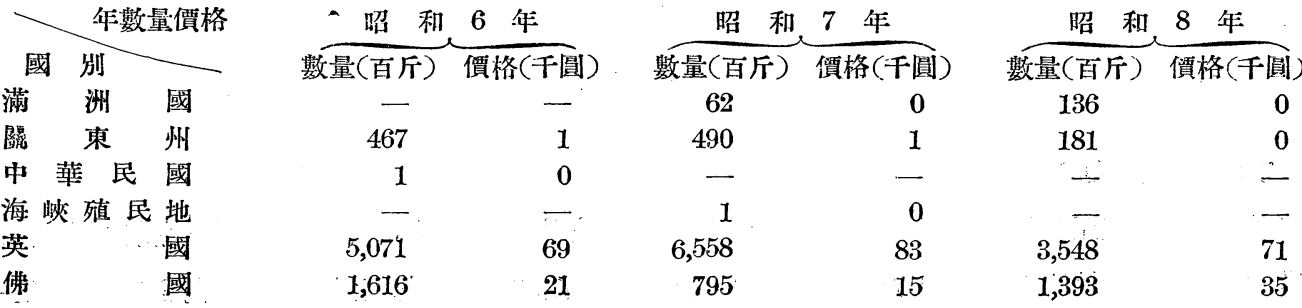




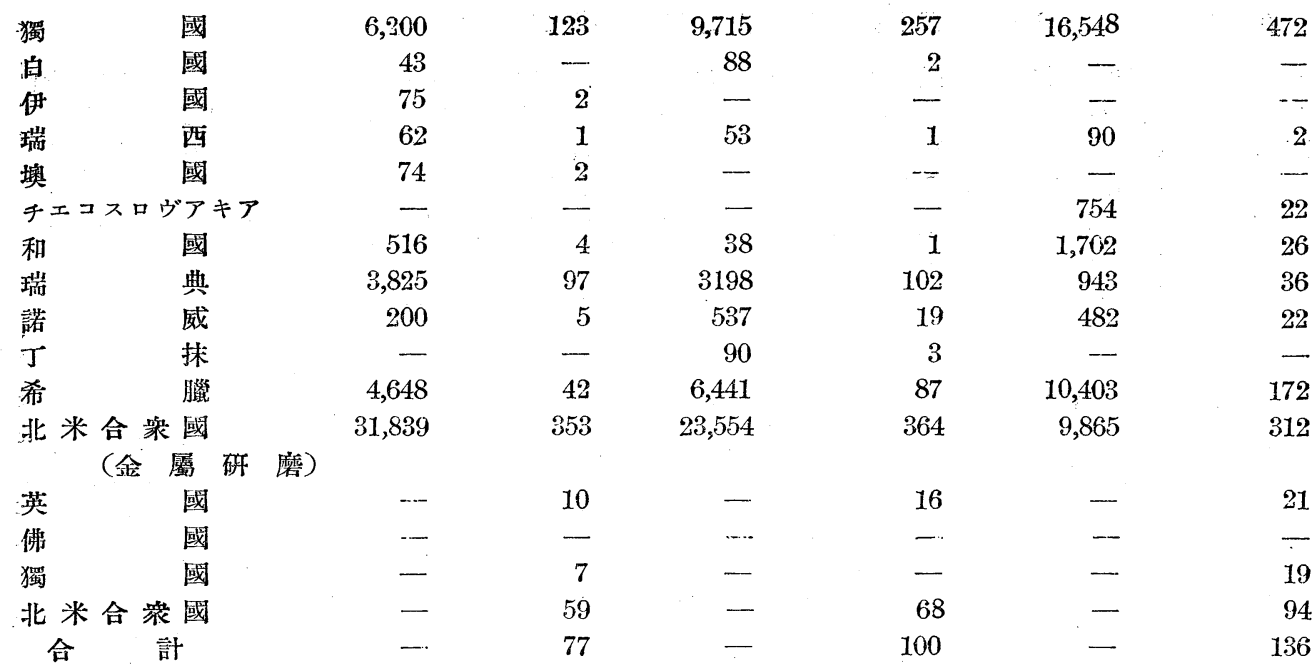

\section{II. 陶磁器，互，土管業の現㫛一覽表}

此種筀業は一般に年々波狀を呈して其產額の盛衰を示し來り大正十三四年頃高潮たりしも一旦減退して去六 七七年前後は最底部に達し更に徐々高況に向ひつ১もり，此情勢は每年每に比較するの要ありとす，更に主要な .る各府縣別の㡾額を示せば次表の通り。

(1) 陶 磁 器

\begin{tabular}{|c|c|c|c|c|c|c|c|c|c|}
\hline \multirow{3}{*}{\multicolumn{2}{|c|}{ 年 次 }} & \multirow{3}{*}{ 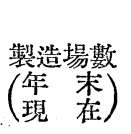 } & \multicolumn{4}{|c|}{ 窯 數 （年末現在） } & \multirow{2}{*}{\multicolumn{3}{|c|}{ 職 工, 數 }} \\
\hline & & & \multicolumn{2}{|c|}{ 本 燒第 } & \multirow{2}{*}{ 錦 聜 } & \multirow{2}{*}{ 素燒薫 } & & & \\
\hline & & & 窯數 & 室數 & & & 男 & 女 & 計 \\
\hline 大正13 & & 7,472 & 2,667 & 10,996 & 2,163 & 3,060 & 32,084 & 12,209 & 44,293 \\
\hline 14 & " & 7,496 & 3,461 & 11,283 & 2,192 & 2,776 & 30,809 & 12,962 & 43,771 \\
\hline 15,1 & " & 7,020 & 3,571 & 10,985 & 2,034 & 3,082 & 32,282 & 13,144 & 45,426 \\
\hline 2 & " & 6,840 & 3,515 & 10,759 & 1,998 & 2,896 & 32,625 & 13,493 & 46,118 \\
\hline 3 & " & 6,862 & 3,526 & 10,734 & 1,999 & 2,783 & 33,117 & 13,991 & 47,108 \\
\hline 4 & " & 6,685 & 3,383 & 10,646 & 1,994 & 2,756 & 31,255 & 13,111 & 44,366 \\
\hline 5 & " & 6,435 & 3,455 & 10,706 & 1,665 & 2,722 & 24,948 & 12,278 & 41,226 \\
\hline 6 & "I & 6,328 & 3,715 & 10,856 & 1,943 & 2,821 & 28,144 & 12,176 & 40,320 \\
\hline 7 & " & 6,474 & 4,024 & 11,152 & 2,052 & 3,189 & 30,416 & 13,529 & 43,948 \\
\hline 8 & " & 6,586 & 3,905 & 10,865 & 1,965 & 3,201 & 37,045 & 16,247 & 53,292 \\
\hline
\end{tabular}

最近数年間に於ける主要生座品別價格表は次表で如何に變化したるが見得べきである。

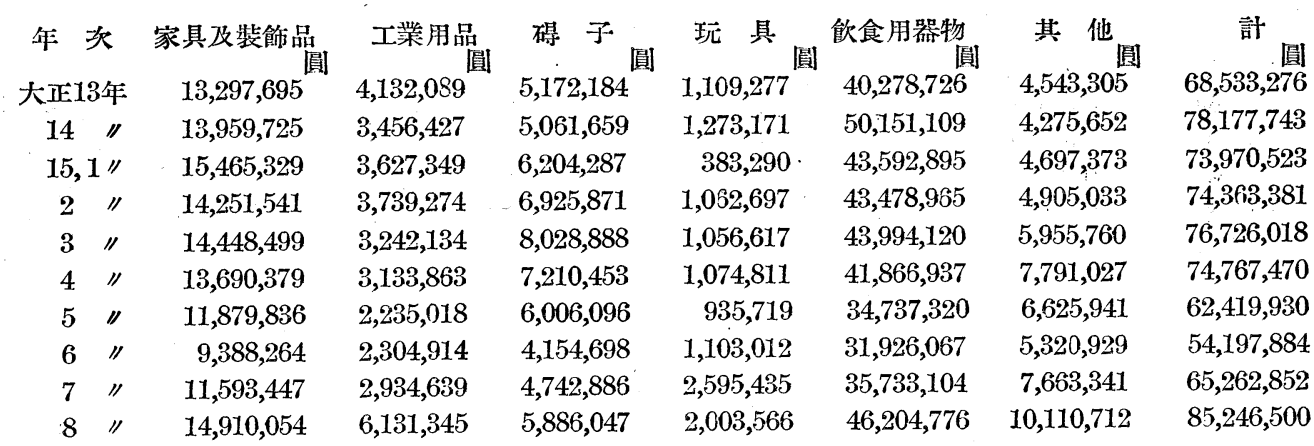


昭和 8 年に於ける主要缸磁器生苼府縣別，金高順序に列擧せば次の通り。

\begin{tabular}{|c|c|c|c|c|c|c|c|c|}
\hline 知 & $46,720,769$ 圓 & 長 & 崎 & 1,150,113圓 & 島 & 290,860 显] & 長 野 & 94,407圓 \\
\hline 轨 & $12,202,859$ & 石 & 川 & $1,084,187$ & 岡 & 276,642 & 鹿兒島 & 89,894 \\
\hline 都 & $6,057,954$ & 兵 & 庫 & $1,016,970$ & 枌 & 202,811 & 苂. 城 & 89,823 \\
\hline 重 & $4,896,058$ & 山 & 口 & 970,380 & 神奈川 & 166,891 & 熊 & 77,098 \\
\hline 阪 & $2,762,710$ & 滋 & 賀 & 806,636 & 愛 媛 & 133,730 & 德 & 74,470 \\
\hline 賀 & $2,616,412$ & 福 & 島 & 582,794 & 香 & 128,084 & 沖 & 67,369 \\
\hline 岡 & $1,808,585$ & 東 & 京 & 330,794 & 城 & 100,200 & & \\
\hline
\end{tabular}

（2）陶管

\begin{tabular}{|c|c|c|c|c|c|c|c|}
\hline 年 & 次 & 製造場数 & 男 & 女 & 計 & 敷 量 & 價＼cjkstart格 \\
\hline 大正13 & & 838 & 2,494 & 491 & 2,985 & $12,107,577$ & $4,925,513$ 溑 \\
\hline 14 & " & 896 & 2,530 & 513 & 3,043 & $10,331,440$ & $3,738,596$ \\
\hline 15,1 & " & 897 & 2,635 & 487 & 3,122 & $11,459,664$ & $3,552,890$ \\
\hline 2 & " & 885 & 2,674 & 434 & 3,108 & $11,674,789$ & $3,728,507$ \\
\hline 3 & " & 878 & 2,717 & 476 & 3,193 & $14,498,353$ & $4,542,070$ \\
\hline 4 & " & 838 & 2,275 & 544 & 3,319 & $18,504,526$ & $4,578,015$ \\
\hline 5 & " & 832 & 2,630 & 520 & 3,150 & $16,919,788$ & $4,301,342$ \\
\hline 6 & " & 784 & 2,456 & 409 & 2,865 & $15,091,654$ & $3,814,048$ \\
\hline 7 & " & 827 & 2,528 & 438 & 2,966 & $13,842,906$ & $3,092,524$ \\
\hline 8 & " & 918 & 2,875 & 435 & 3,310 & $15,746,529$ & $3,760,772$ \\
\hline
\end{tabular}

陶管の主要生產府縣別を生產高順に列擧せば次の如し。

\begin{tabular}{|c|c|c|c|c|c|c|c|c|c|c|}
\hline 知 & 2,395,942圓 & 山 & 口 & 103,600㨪 & 福 & 网 & 80,741圓 & & 川 & 85,209 圓] \\
\hline 阪 & $1,159,888$ & 宮 & 城 & 99,597 & 熊 & 本 & 78,515 & 茨 & 城 & 32,390 \\
\hline 都 & 148,964 & 岡 & 山 & 90,257 & 兵 & 庫 & 69,463 & 福 & 井 & 32,390 \\
\hline
\end{tabular}

(3) 瓦業

\begin{tabular}{|c|c|c|c|c|c|c|c|c|c|}
\hline \multirow[b]{2}{*}{ 年 } & \multirow[b]{2}{*}{ 次 } & \multirow[b]{2}{*}{ 製造場做 } & \multicolumn{3}{|c|}{ 職工(數年末現在) } & \multicolumn{2}{|c|}{ 屋根用平瓦 } & \multirow{2}{*}{$\begin{array}{ll}\text { 其 他 } \\
\text { 價 格 }\end{array}$} & \multirow[b]{2}{*}{ 價 格 計 } \\
\hline & & & 男 & 女 & 話 & 數 量 & 價 格 & & \\
\hline 大正13 & & 13,071 & 34,367 & 7,595 & 41,962 & $8,959,706$ 坪 & 47,924,790圓 & $4,280,022$ 圓] & $52,204,812$ 圓! \\
\hline 14 & " & 13,104 & 34,154 & 7,608 & 41,762 & $8,588,890$ & $44,397,633$ & $3,794,950$ & $48,192,583$ \\
\hline 15,1 & " & 13,140 & 34,026 & 7,569 & 41,595 & $584,413,634$ & $33,974,936$ & $4,728,856$ & $38,703,792$ \\
\hline 2 & " & 12,915 & 34,323 & 7,573 & 41,896 & $563,889,210$ & $30,213,047$ & $4,212,414$ & $34,425,461$ \\
\hline 3 & " & 13,012 & 34,963 & 7,942 & 42,905 & $597,236,091$ & $29,814,424$ & $4,306,004$ & $34,120,428$ \\
\hline 4 & " & 12,485 & 33,231 & 7,464 & 40,695 & $601,653,158$ & $26,868,109$ & $3,733,339$ & $30,601,448$ \\
\hline 5 & " & 11,962 & 31,005 & 7,061 & 38,066 & $511,005,536$ & $19,752,659$ & $2,887,521$ & $22,640,180$ \\
\hline 6 & " & 11,725 & 31,002 & 6,980 & 38,072 & $522,970,551$ & $18,345,402$ & $2,654,000$ & $20,999,402$ \\
\hline 7 & " & 11,445 & 31,114 & 7,154 & 38,268 & $521,799,670$ & $18,070,815$ & $2,784,285$ & $20,855,100$ \\
\hline 8 & " & 11,213 & 30,624 & 7,004 & 37,628 & $515,714,667$ & $19,125,574$ & $3,111,841$ & $22,237,415$ \\
\hline
\end{tabular}

昭和 8 年に於ける瓦の主要生產府縣別を生產高順に列擧すれば次の通り。

\begin{tabular}{|c|c|c|c|c|c|c|c|c|c|c|c|}
\hline 兵 & 庫 & $3,189,625$ 傊 & 埥 & 阔 & 730,868 渾 & 岐 & 阜 & 607,768 橮 & & 山 & 514,340 㥧 \\
\hline 愛 & 知 & $2,460,507$ & $\equiv$ & 重 & 720,735 & 香 & 川 & 607,100 & 京 & 都 & 502,947 \\
\hline 福 & 岡 & $1,445,570$ & 島 & 根 & 615,805 & 石 & 川 & 606,330 & 德 & 島 & 464,291 \\
\hline 大 & 阪 & 991,354 & 滋 & 賀 & 613,602 & 埼 & 玉 & 549,192 & 福 & 井 & 445,563 \\
\hline 愛 & 媛 & 741,388 & 山 & 口 & 608,647 & 奈 & 良 & 518,809 & 富 & 山 & 433,892 \\
\hline
\end{tabular}

